\title{
POLICY IMPLEMENTATION PERFORMANCE RELATED TO THE PROCUREMENT OF PRB DRUGS IN THE SUBDISTRICT PRIMARY HEALTHCARE CENTER PHARMACY AND PRB PHARMACY IN CENTRAL JAKARTA QUARTER I, II, AND III OF 2019
}

\author{
Sari Ulfa Nardia ${ }^{1}$, Amal Chalik Sjaaf ${ }^{2}$ \\ ${ }^{1}$ Health Policy and Administration, Faculty of Public Health, Universitas Indonesia, \\ Kampus Depok, Jawa Barat, 16425, Indonesia \\ ${ }^{2}$ Health Policy and Administration, Faculty of Public Health, Universitas Indonesia, \\ Kampus Depok, Jawa Barat, 16425, Indonesia
}

Email : sari.ulfanardia@gmail.com

\begin{abstract}
Back-Referral Program (PRB) is one way to improve the quality of the health services for BPJS participants in conducting quality control and cost control. The unavailability of pharmacies and drugs for PRB causes the PRB program not to run optimally, thus increasing the catastrophic disease sufferers and absorbing big claims in JKN. This study is qualitative research with a descriptive approach using the method of in-depth interviews and document review. The research informants' criteria were: the elements of the leadership and policy management officers in the DKI Jakarta Provincial Health Office, Central Jakarta Health Office, Central Jakarta BPJS Health Center, Central Jakarta District Health Center, and Central Jakarta PRB Pharmacy. The results showed that the implementation performance was not optimal, which was influenced by policy standards and objectives, resources, communication between organizations, the implementers' attitude, the implementing organization's characteristics, and the economic, social, and politics. Coordination, commitment, and evaluation of activities from the Ministry of Health, BPJS Health, Government Service Goods Procurement Policy Institute, and DKI Jakarta Provincial Health Office are needed in terms of the availability of this PRB drug
\end{abstract}

Keywords: Implementation, Policy, Back - Referral Program, Drug

\begin{abstract}
Abstrak. Program Rujuk Balik (PRB) merupakan salah satu cara meningkatkan kualitas pelayanan kesehatan bagi peserta BPJS dalam melakukan kendali mutu dan kendali biaya. Ketersediaan Apotek PRB dan ketidaktersediaan obat di Apotek PRB menyebabkan PRB bagi pasien yang membutuhkan obat berjalan tidak maksimal, dapat meningkatkan penderita penyakit katastropik dan menyerap klaim besar dalam JKN. Penelitian ini adalah penelitian kualitatif dengan pendekatan deskriptif menggunakan metode wawancara mendalam dan telaah dokumen. Kriteria informan penelitian adalah unsur pimpinan dan petugas pengelola kebijakan pada Dinas Kesehatan Provinsi DKI Jakarta, Suku Dinas Kesehatan Jakarta Pusat, BPJS Kesehatan Cabang Jakarta Pusat, Subdistrict primary healthcare Se-Jakarta Pusat dan Apotek PRB Se-Jakarta Pusat. Hasil penelitian menunjukkan bahwa kinerja implementasi belum optimal yang dipengaruhi oleh standar dan sasaran kebijakan, sumber daya, komunikasi antar organisasi, sikap para pelaksana, karakteristik organisasi pelaksana dan lingkungan ekonomi, sosial serta politik. Diperlukan koordinasi, komitmen dan evaluasi kegiatan dari Kementerian Kesehatan, BPJS Kesehatan, Lembaga Kebijakan Pengadaan Barang/Jasa Pemerintah (LKPP) serta Dinas Kesehatan Provinsi DKI Jakarta dalam hal ketersediaan obat PRB ini.
\end{abstract}

Kata Kunci : Implementasi, Kebijakan, Program Rujuk Balik, Obat

\section{INTRODUCTION}

Referral Program Services (PRB) are health services provided to patients with chronic diseases with stable conditions and still need long-term treatment or nursing care at the First Level Health Care Services (FKTP) on recommendation/referral from the treating Specialist/Sub Specialist. The scope of PRB includes
Diabetes Mellitus, Hypertension, Heart, Asthma, Chronic Obstructive Pulmonary Disease (COPD), Epilepsy, Schizophrenia, Stroke, and Systemic Lupus Erythematosus (SLE) . ${ }^{1}$

Drug unavailability at PRB Pharmacy is one of the problems of maintaining quality and cost control. Research at BPJS Kesehatan Central Jakarta in June - 
August 2014 showed that PRB drug unavailability was found from the unserved drug demand, which was $43.2 \%$ participants in June, $15.2 \%$ participants in July, and $9.7 \%$ participants in August 2014.2 Therefore, many patients buy their own drugs or do not even consume drugs that trigger catastrophic diseases.

Catastrophic health spending can lead to impoverishment. The indirect economic impact of chronic disease is reduced income due to lost productivity due to illness or death, reduced opportunities for savings, and loss of employment or education opportunities. Groups of catastrophic diseases such as kidney failure, cardiovascular, cancer, thalassemia, and hemophilia create the most significant spending from the National Health Insurance (JKN), absorbing large claims in JKN and need serious attention. $^{3}$

On 5 September 2019 in Jakarta, Director of BPJS Health Service Security, Maya A Rusadi, stated that in the BPJS records that catastrophic diseases cost Rp. 11.07 trillion in 2014, Rp. 14.88 trillion in 2015, Rp. 16.94 trillion in 2016, IDR 18.44 trillion in 2017, IDR 20.42 trillion in 2018, and approximately IDR 10 trillion in June 2019. This condition also happened with an increasing number of participants.

Central Jakarta BPJS data shows 8 PRB pharmacies in Central Jakarta out of 293 Pharmacies at the beginning of 2019. The unavailability of PRB Pharmacies drugs at the PRB Pharmacy caused the PRB program not to be optimal. Even though sub-district primary healthcare has an E-catalog system to optimize drug availability, many still cannot run PRB optimally.

The purpose of this study was to determine the performance of policy implementation related to the availability of PRB drugs in the sub-district health center pharmacy room and PRB pharmacy in Central Jakarta for the first, second, and third quarters of 2019 based on the Republic of Indonesia Minister of Health Regulation Number 99 of 2015 concerning health services on JKN article 25. To ensure PRB drugs' availability, BPJS Kesehatan must collaborate with pharmacies or pharmacy installations in FKTPs that are easily accessible to JKN participants. ${ }^{5}$

According to Dunn (2004), there are three policy elements: political actors, policy environment, and public policies.6 Policy implementation is the fourth stage after the agenda-setting, policy formulation, and policy adoption stages, followed by the policy evaluation stage in the policy formulation or development cycle. 7 To determine the performance of policy implementation in this study, we use a policy model theory according to Van Meter and Van Horn.

Van Meter and Van Horn's policy model states that policy implementation runs linearly from public policy, implementor, and public policy performance.
Six variables that influence public policy are policy standards and objectives, resources, characteristics of the implementing organization, communication between related organizations and implementation activities, dispositions or attitudes of the implementers, and the social, economic, and political environment. ${ }^{8}$

\section{METHOD}

This research is qualitative research with a descriptive approach using in-depth interviews and document review. The research location is at the DKI Jakarta Health Office, City Health Office, BPJS office, eight district primary health care, and eight PRB Pharmacies in Central Jakarta. This research has received a recommendation letter from the Ethics Commission for research and community health service, Faculty of Public Health, University of Indonesia number: 411 / UN2.F10 / PPM.00.02 / 2019 dated 11 June 2019.

The research informants were the Head of the Food and Beverage Pharmacy Section of the DKI Jakarta Health Office (1 person), the Heads of the District Primary Healthcare (7 people), the chief of Pharmacy at the Health Office (1 person), head pharmacist for the District Primary Healthcare (8 people), the Pharmacist in charge of the PRB Pharmacy (9 people), and the head branch of BPJS Primary Benefit Insurance (1 person) in the Central Jakarta area. Informed consent was given to informants before the researchers took primary and secondary data.

The data analysis procedure steps: informant descriptions, compiling transcript notes, data organization, data categorization/coding, summarizing data into matrices, identifying variables and relationships between variables, and drawing conclusions. The data triangulation approach uses technical triangulation, data retrieval utilizing in-depth interviews, observation, document review, and source triangulation by collecting data from several informants and comparing data obtained from one informant with other informants.

\section{RESULT AND DISCUSSION}

\section{Kinerja Implementasi Kebijakan terkait Penyediaan Obat PRB}

In the 3rd quarter of 2019, pharmacies that collaborate with BPJS Kesehatan in providing PRB drugs are Kimia Farma 1 Garuda Pharmacy, Kimia Farma 2 Senen Pharmacy, Kimia Farma 5 Cikini Pharmacy, Kimia Farma 6 Pejompongan Pharmacy, 198 Kimia Farma Pharmacy Percetakan Negara, a Pharmacy Kimia Farma 298 Bendungan Hilir, Kimia Farma Pharmacy Menteng Huis, Pharmacy Sana Farma Percetakan Negara, Sawah 
Besar District Primary Healthcare and Kemayoran District Primary Healthcare.

The Head of the DKI Jakarta Provincial Health Office did the first socialization of PRB drugs for primary healthcare at the Regional Health Work Meeting in April 2019. DRR drugs, provided for district primary healthcare as a Pilot Project, are for hypertension diagnosis without any complications. The PRB Pharmacist serves 8 Other diagnoses at the primary healthcare pharmacy room. Another primary healthcare provides a pharmacy room for the PRB Pharmacist, while the remaining five Primary healthcare are waiting for instructions and planning preparations.

Obstacles faced in implementing policies were:

1. The procurement of PRB DRR drugs was done suddenly in the middle of the year budget. Primary healthcare cannot do planning for drugs that are not FKTP drugs or outside the Fornas PRB drugs. There is still no derivative of the legal aspect. There is no data on the drug types, the number of PRB drugs, and the number of PRB patients that should be served at the primary healthcare.

2. The PRB pharmacy. The PRB pharmacy cannot buy drugs through e-purchasing or combining PRB drugs with other drugs for the pharmacy, resulting in drug unavailability. The information provided by the hospital for patients is lacking. Primary healthcare does not directly enter the visit number; thus, it cannot be read in online pharmacies. Patients sometimes no longer take PRB drugs for various reasons, such as worsening conditions, moving to other healthcare facilities. Officers are less accustomed to open online applications.

3. The triangulation results are: the availability of pharmacies and PRB drugs, the unavailability of epurchasing accounts at PRB pharmacies, replacement of regular drugs with e-catalog prices, availability of facilities and infrastructure, PRB recruitment with the willingness of specialist doctors to refer back, drugs do not meet the FORNAS criteria, PIC PRB at the hospital does not know about PRB drugs and their restrictions, patients not being referred back by the specialist at the hospital, and there are no recommendation criteria to determine stable patients who can be referred back.

There are two pharmaceutical services in one pharmacy room for certain days at the three districts' primary healthcare. As a consideration in Law Number 36 of 2014 concerning health workers article 46 paragraphs 1,2 and 5 and Permenkes RI, Number 74 of 2016 concerning standards of pharmaceutical services in primary healthcare, article 7 and article 3 paragraph 1 stated that the pharmacy staff of the PRB Pharmacy service that provides pharmaceutical services in the primary healthcare pharmacy must have SIPA (license).9,10 Also, PRB Pharmacist that provides PRB drug pharmaceutical services in the primary healthcare pharmacy room still has to carry out standard pharmaceutical services for PRB Pharmacy.

Research by Paramita A et al. (2019) reported that the main problems of PRB implementation are: the limited availability of PRB drugs in primary healthcare, prolonged queue time because of patients accumulation in the hospital, notification of "potential PRB" status on patients in the VCLAIM program at the hospital tends to be ignored, low compliance of medical personnel in the hospital in completing the referral form feedback, and the lack of socialization of PRB program to the community. ${ }^{11}$

Tabel 1. Recapitulation of Policy Implementation Performance related to the procurement of PRB drugs in the Subdistrict Primary Healthcare Center Pharmacy room and PRB Pharmacy in Central Jakarta Quarter I, II, and III of 2019

\begin{tabular}{|c|c|c|c|c|c|c|c|}
\hline \multirow[t]{2}{*}{ No } & \multirow[t]{2}{*}{ Indicators } & \multicolumn{2}{|c|}{ Not Yet Started } & \multicolumn{2}{|c|}{$\begin{array}{l}\text { Has Started but } \\
\text { not yet optimal }\end{array}$} & \multicolumn{2}{|c|}{$\begin{array}{c}\text { Has been } \\
\text { optimal }\end{array}$} \\
\hline & & $\mathrm{PHC}$ & Phar & PHC & Phar & PHC & Phar \\
\hline 1 & $\begin{array}{l}\text { Policy standards } \\
\text { and objectives }\end{array}$ & & & $V$ & $\sqrt{ }$ & & \\
\hline 2 & Human resources & & & $\sqrt{ }$ & $\sqrt{ }$ & & \\
\hline 3 & Funding & & & $\sqrt{ }$ & $\sqrt{ }$ & & \\
\hline 4 & Time & & & $\sqrt{ }$ & $\sqrt{ }$ & & \\
\hline 5 & $\begin{array}{l}\text { Facility } \\
\text { procurement }\end{array}$ & & & & & $\sqrt{ }$ & $\sqrt{ }$ \\
\hline 6 & $\begin{array}{l}\text { Easy access (e- } \\
\text { monev, e-catalog) }\end{array}$ & & $\sqrt{ }$ & & & $\sqrt{ }$ & \\
\hline 7 & Incentive & $\sqrt{ }$ & $\sqrt{ }$ & & & & \\
\hline 8 & $\begin{array}{l}\text { Interorganizationa } \\
1 \text { communication }\end{array}$ & & & $\sqrt{ }$ & $\sqrt{ }$ & & \\
\hline 9 & $\begin{array}{l}\text { communication } \\
\text { transmission }\end{array}$ & & & $\sqrt{ }$ & $\sqrt{ }$ & & \\
\hline 10 & $\begin{array}{l}\text { information } \\
\text { consistency }\end{array}$ & & & $\sqrt{ }$ & $\sqrt{ }$ & & \\
\hline 11 & $\begin{array}{l}\text { Information } \\
\text { clarity }\end{array}$ & & & $\sqrt{ }$ & $\sqrt{ }$ & & \\
\hline 12 & Implanter attitude & & & $\sqrt{ }$ & $\sqrt{ }$ & & \\
\hline 13 & $\begin{array}{l}\text { Commitment } \\
\text { strategy }\end{array}$ & & & $\sqrt{ }$ & $\sqrt{ }$ & & \\
\hline 14 & $\begin{array}{l}\text { Organizational } \\
\text { structure } \\
\text { fragmentation }\end{array}$ & & & & $\sqrt{ }$ & $\sqrt{ }$ & \\
\hline 15 & $\begin{array}{l}\text { Standard } \\
\text { operational } \\
\text { procedure }\end{array}$ & & & $\sqrt{ }$ & $\sqrt{ }$ & & \\
\hline 16 & $\begin{array}{l}\text { Social } \\
\text { environment }\end{array}$ & & & & & $\sqrt{ }$ & $\checkmark$ \\
\hline 17 & Economic & & & $\sqrt{ }$ & $\sqrt{ }$ & & \\
\hline 18 & Politic & & & & & $\sqrt{ }$ & $\sqrt{ }$ \\
\hline
\end{tabular}

*PHC: Primary Healthcare Center, Phar: Pharmacy

\section{Policy standards and objectives}

There are still obstacles in policy implementation performance in the monitored indicators so that it is not optimal according to the target and the number of collaborators.

\section{Resources}

2 out of 8 subdistricts primary healthcare center have only one pharmacist. Human resources at PRB Pharmacy are sufficient. From the triangulation, we found that the pharmacy services at the Pharmacy and 
primary healthcare center have not been implemented optimally, and many of the PRB Pharmacists are not on standby during service hours. In the Republic of Indonesia Minister of Health Regulation No.43 of 2019 concerning primary healthcare center and workforce standards, to increase the number of services PRB drugs and maximize the standard of pharmaceutical services, more than one pharmacist is needed. ${ }^{12}$

The primary healthcare center drug budget was from the regional public service agencies. PRB pharmacies budget from private and state-owned funds. The drug planning process starts from preparing online planning through the e-monev system, procurement / epurchasing through the e-catalog system, or other programs according to the Presidential Regulation on Procurement of $\mathrm{B} / \mathrm{J}$ by the Government. All PRB Pharmacies in Central Jakarta in the 1st, 2nd, and 3rd quarter of 2019 have not received an e-monev account. A policy or program will not be able to achieve its goals or objectives without adequate budget support. ${ }^{13}$

The procurement of PRB drugs by the dispensary pharmacy needs to be adjusted to the Republic of Indonesia Minister of Health Regulation No. 9 of 2017 concerning Pharmacy, article 17 paragraph 1 letter a and paragraph 2, which states "Pharmacy can only submit pharmaceutical preparations, medical supplies, and consumable medical materials to other pharmacies to meet the shortage in the number of preparations." 14

Hann (2007) stated that there are two alternative policy implementations: implementing them in the form of programs or making derivative policies.7 This is related to the need for a legal umbrella in providing PRB drugs in primary healthcare center. Research by Maryani H, Kristiana L, Andarwati P, Paramita A, and Aimanah IU (2019) stated that "another obstacle faced by primary healthcare center is that some drugs that are already included in the list of DRR drugs in the hospital are still not included in PRB drugs in primary healthcare center." 15

PRB drugs often unavailable at PRB Pharmacies are Irbesartan $150 \mathrm{mg}$, Irbesartan $300 \mathrm{mg}$, Diovan, Sopralan, Miniaspi, Adalat Oros, ISDN, Diamicrone, and Phenytoin. This condition follows the Annex to Permenkes RI No.28 of 2014 concerning the JKN Program Implementation Program; chapter IV letter D number 2 concerning drug supply has not been fulfilled. ${ }^{16}$

\section{Communication between Organizations}

Policy transmissions are delivered through meetings, WA groups, telegrams, and letters addressed to PRB Pharmacies and Primary healthcare centers. Not all of them understand the information provided regarding PRB. The transmission of understanding in forwarding policy messages is not optimal at the executive level. George C. Edwards stated that if we want to make policy implementation effective, then implementation orders must be consistent and clear. ${ }^{17}$

\section{The attitude of the implementers}

Initially, some primary healthcare centers refused to implement the program. Only pharmacies that can fund the programs accepted the policy implementation. Moreover, the Central Jakarta BPJS Kesehatan has not implemented a reward and punishment system. George C. Edwards argues that one of the techniques suggested high-level policymakers overcome the likelihood of implementers by manipulating incentives such as reward/punishment so that it is likely to influence policy implementers' actions. ${ }^{17}$

\section{Characteristics of the Implementing Organization}

Fragmentation of the organizational structure subdistrict primary healthcare supports implementing PRB drugs procurement policies because of the accreditation. PRB pharmacies have not implemented optimally Permenkes No. 73 of 2016. Primary healthcare providers of PRB drugs already have their own SOPs, but not all PRB Pharmacies. SOPs uniformity is the officials' actions in complex and widespread organizations and has significant similarity in applying regulations. ${ }^{17}$

\section{The Economic, Social, and Political Environment}

The social environment inside and outside the Health Office, Primary healthcare, and PRB Pharmacy support the procurement and service of PRB drugs. Implementation in Subdistrict Primary Healthcare is supported by the Head of the Health Office and the Governor of DKI Jakarta Province. The leader of the Pharmacy also supports implementation at the Pharmacy. Because not all primary healthcare has the same amount of BLUD income, it requires a legal umbrella in PRB drug procurement management. There are still PRB participants who prefer to seek treatment and meet specialist doctors at the hospital. Hospitals have an essential role in the successful implementation of PRB policies in line with previous studies. $^{11,18}$

\section{CONCLUSION}

The implementation of policies related to the procurement of PRB drugs in the subdistrict primary healthcare pharmacy room and PRB Pharmacy in Central Jakarta for the first, second, and third quarter of 2019 have been carried out by 8 PRB pharmacies from 293 pharmacies and 2 out of 8 subdistricts primary healthcare as pilot projects with not optimal results. The following reasons are:

1. Subdistrict primary healthcare: The attitude, response, and commitment of the implementers 
are influenced by the support of the economic environment, the availability of SOPs, the absence of a particular legal umbrella, and communication between organizations which includes clarity, method, consistency in delivery, objectives and policy objectives. Not all of the resources involved have a clear understanding of the standards and policy objectives. It is also affected by the fulfillment of resources, including the availability of human resources for pharmaceutical services in several sub-districts primary healthcare, the availability of funds/budgets that affect the PRB drug planning process, the time required for drug fulfillment, and the absence of incentives or rewards and punishments.

2. PRB Pharmacy: The attitude, response, and commitment of the implementer are influenced by the support of the economic environment, the availability of SOPs, and the pharmacy's organizational structure as well as communication between organizations which includes clarity, method, consistency of delivery, policy objectives, and objectives, fulfillment of human resource discipline, availability of funds/budget, the PRB drug planning process, the time needed to fulfill the drugs, the absence of incentives or rewards/punishments, and the lack of easy access to orders through e-catalogs in the process of procuring DRR drugs.

\section{SUGGESTIONS}

\section{Ministry of Health of the Republic of Indonesia:}

1. Disseminate the policies issued so that implementers can understand, have the same perception, and do not have different interpretations to support health services optimization.

2. Compile data collection of FORNAS drugs that are not available in e-catalog shows and find solutions to display all PRB drugs.

3. Provide e-purchasing access through an e-catalog account to PRB Pharmacies and other health facilities that have sent RKOs on the e-monev application system.

4. Create policies and a strict monitoring system so that e-purchasing access to the e-catalog can only be used for health facilities/pharmacies that have submitted RKOs through the e-monev application system.

5. Create policies that regulate the granting of sanctions to the pharmaceutical industry and drug distributors who are in default.

6. Create policies to coordinate with relevant collegium to provide PRB requirements for patients for the specialist doctor in FKTRL/hospital.

\section{BPJS Kesehatan}

Coordinate with the Health Office in formulating PRB policies in DKI Jakarta.

\section{BPJS Kesehatan Central Jakarta Branch:}

1. Disseminate BPJS Kesehatan policies appropriately to the management elements and field technical officer so that these policies can be understood and implemented correctly.

2. Create a patient and PRB drugs information system for primary healthcare, PRB Pharmacy, and other health facilities to facilitate PRB drug planning and minimize the occurrence of drug planning errors.

3. Create a system of guidance, monitoring, and evaluation at the primary healthcare facility, hospital, and PRB Pharmacy with a rewards/punishments system to increase commitment to PRB and shorten verification process time of drug claim files; thus, speed up the time for claim payments.

\section{DKI Jakarta Provincial Health Office:}

1. Create a derivative legal umbrella policy as a reference for the Subdistrict Primary Healthcare in planning, procurement, and PRB drugs service by paying attention to compliance with pharmaceutical service standards in primary healthcare.

2. Disseminate and ensure implementers understand, have the same perception, and do not have different interpretations of each Health Office policy.

3. Periodically monitor and evaluate the implementation of policies to achieve policy objectives and targets.

4. Evaluate and control constraints in the field with the relevant sectors.

\section{Central Jakarta Health Office}

Increase development, supervision, and control activities to the primary healthcare, pharmacies, and other health facilities.

\section{LKPP:}

1. Improve coordination with the Ministry of Health and BPOM in monitoring and evaluating the process of government procurement of goods/services as a basis for formulating policies.

2. Implement rewards and punishments to the government drug goods/services providers. 


\section{Next Researcher:}

Include elements from the Ministry of Health and FKTRL/Hospital as research informants.

\section{REFERENCES}

1. BPJS Kesehatan, (2014) . Panduan Praktis Program Rujuk Balik Bagi Peserta JKN

2. Ianathasya dan Nadjib M (2015). Gambaran Stock Out Obat Program Rujuk Balik bagi peserta JKN di BPJS Kesehatan Jakarta Pusat pada Bulan Juni - Agustus 2014, Depok : Fakultas Kesehatan Masyarakat Universitas Indonesia

3. Heniwati dan Thabrany H.(2016). Perbandingan Klaim Penyakit Katastropik Peserta Jaminan Kesehatan Nasional di Provinsi DKI Jakarta dan Nusa Tenggara Timur Tahun 2014. Jurnal Ekonomi Kesehatan Indonesia, Vol. 1 (2), 18-27

4. Cahyadi, A. (2019). BPJS Kesehatan Prediksi Biaya Penyakit Katastropik Tembus Rp20 Triliun.https://investor.id/finance/bpjskesehatan-prediksi-biaya-penyakitkatastropik-tembus-rp20-triliun. diakses Juli 26, 2020

5. Kementerian Kesehatan Republik Indonesia RI. (2015). Peraturan Menteri Kesehatan Republik Indonesia Nomor 99 Tahun 2015 tentang Perubahan atas Peraturan Menteri Kesehatan Republik Indonesia Nomor 71 Tahun 2013 tentang Pelayanan Kesehatan pada Jaminan Kesehatan Nasional. Jakarta

6. Lembaga Administrasi Negara. (2015). Modul Pelatihan Analisis Kebijakan.

https://www.ksiindonesia.org/old/document/material/144 712564312XL90.pdf

7. Ayuningtyas, D. (2015). Kebijakan Kesehatan Prinsip dan Praktik (1st ed.). Jakarta: Rajawali Pres

8. Nugroho, Riant ( 2017). Public Policy (Edisi Keenam). Jakarta : PT Gramedia

9. Republik Indonesia. (2014). Undang-Undang Republik Indonesia Nomor 36 tahun 2014 tentang Tenaga Kesehatan. Jakarta.

10. Kementerian Kesehatan Republik Indonesia RI. (2016). Peraturan Menteri Kesehatan Republik Indonesia Nomor 74 tahun 2016 tentang Standar Pelayanan Kefarmasian di Primary healthcare . Jakarta
11. Paramita A, Andarwati P, Kristiana L (2019). Upaya Kendali Mutu dan Biaya Program Rujuk Balik Menggunakan Pendekatan Root Cause Analysis.Cost and Quality Control in Referral - Back Programme using Root Cause Analysis. Journal of Health Science and Prevention Vol 3 No 2 September 2019ISSN 2459-919x : 68-78

12. Kementerian Kesehatan Republik Indonesia RI. (2019). Peraturan Menteri Kesehatan Republik Indonesia Nomor 43 tahun 2019 tentang Pusat Kesehatan Masyarakat. Jakarta

13. Purwanto, EA \& Sulistyastuti, DR 2015, Implementasi Kebijakan Publik : Konsep dan Aplikasinya di Indonesia, Penerbit Gava Media, Yogyakarta.

14. Kementerian Kesehatan Republik Indonesia RI. (2017). Peraturan Menteri Kesehatan Republik Indonesia Nomor 9 tahun 2017 tentang Apotek . Jakarta

15. Maryani H, Kristiana L, Andarwati $P$, Paramita A, dan Aimanah I U (2019). Pengelolaan Obat dengan E-Purchasing untuk pasien Program Rujuk Balik di Fasilitas Kesehatan tingkat Pertama ( Studi kasus di Primary healthcare dan Apotek di Surabaya ). Buletin Penelitian Sistem Kesehatan - Vol. 22 No. 2 April 2019: 99-105

16. Kementerian Kesehatan Republik Indonesia RI. (2014). Peraturan Menteri Kesehatan Republik Indonesia Nomor 28 tahun 2014 tentang Pedoman Pelaksanaan program JKN (Lampiran). Jakarta

17. Winarno, B 2014, Kebijakan Publik : Teori, Proses dan Studi Kasus, Center of Academic of Publishing Service, Yogyakarta.

18. Pertiwi D, Wigati PA, Fatmasari EY (2017) Analisis Implementasi Program Rujuk Balik Peserta Jaminan Kesehatan Nasional di Rumah Sakit Umum Daerah Tidar Kota Magelang. JURNAL KESEHATAN MASYARAKAT (e-Journal) Volume 5, Nomor 3, Juli 2017 (ISSN: 2356-3346) http://ejournals1.undip.ac.id/index.php/jkm 